\title{
$\widehat{A}$ Madridge \\ madridge Journal of Cancer Study \& Research \\ Interconnecting Scientific World
}

Research Article

Open Access

\section{Combined Human Epididymis 4 and Carbohydrate Antigen 125 Serum Protein Levels Diagnostic value in Ovarian Cancer}

\author{
Salwa Hassan Teama ${ }^{1 \star}$, Reham El Shimy ${ }^{2}$ and Hebatallah Gamal ${ }^{3}$ \\ 'Department of Molecular Biology, Medical Ain Shams Research Institute (MASRI), Faculty of Medicine, Ain Shams University, Cairo, \\ Egypt \\ ${ }^{2}$ Department of Clinical and Chemical Pathology, National Cancer Institute, Faculty of Medicine, Cairo University, Cairo, Egypt \\ ${ }^{3}$ Departement of Surgical Oncology, National Cancer Institute, Faculty of Medicine, Cairo University, Cairo, Egypt
}

\section{Article Info}

*Corresponding author:
Salwa Hassan Teama
Department of Molecular Biology
Medical Ain Shams Research Institute
(MASRI)
Faculty of Medicine
Ain Shams University
Abbasia, Cairo
Egypt
Tel: 0020-1005293116
E-mail: salwateama2004@yahoo.com

Received: July 25, 2018

Accepted: August 13, 2018

Published: August 17, 2018

Citation: Teama S, El Shimy R, Gamal H. Combined Human Epididymis 4 and Carbohydrate Antigen 125 Serum Protein Levels Diagnostic value in Ovarian Cancer. Madridge J Cancer Stud Res. 2018; 2(1): 59-64.

doi: $10.18689 / \mathrm{mj}$ csr-1000108

Copyright: (c) 2018 The Author(s). This work is licensed under a Creative Commons Attribution 4.0 International License, which permits unrestricted use, distribution, and reproduction in any medium, provided the original work is properly cited.

Published by Madridge Publishers

\begin{abstract}
Objective: Human Epididymis 4 (HE-4) protein, a new candidate for ovarian cancer detection shows promising diagnostic value for ovarian cancer diagnosis, this study aimed to assess the diagnostic significance of combined Human Epididymis 4 and Carbohydrate Antigen 125 (CA-125) serum protein levels in ovarian cancer detection.
\end{abstract}

Subjects and Methods: A clinical case control study include; forty nine subjects; patients with ovarian cancer $(n=33)$, non-cancer control group $(n=16)$. Serum protein levels of $\mathrm{HE}-4$ were measured using an enzyme linked immune sorbent assay (ELISA). All data were analyzed by SPSS software (version 21.0.0; IPM SPSS, Chicago, IL, USA).

Results: The results showed that increased serum protein concentration of $\mathrm{HE}-4(\mathrm{pMol} / \mathrm{L})$ and CA-125 (U/ml) in the ovarian cancer group mean (SD)/median (range) 329.61 $\pm 336.55 / 199$ (28.72-1064) and 521.36 $\pm 572.60 / 287$ (10.50-2377), than non-cancer control group $64.80 \pm 38.51 / 54.53(21-160)$ and $28.35 \pm 10.80 / 28(10-50)$ respectively $(p<0.05)$. The receiver operating characteristic curve, the area under the curve (ROC-AUC) $(95 \% \mathrm{Cl})$ values of serum HE-4 was 0.85 (0.74-0.95). The sensitivity and specificity of HE-4 in diagnosing malignant ovarian tumors was $84.84 \%$ and $75.00 \%$, respectively at ideal cutoff point that provided the best and highest accuracy in our own study and its level was related to clinical staging.

Conclusion: Our study concludes that HE-4 protein a new candidate biomarker has a comparable diagnostic value for ovarian cancer detection compared to CA-125 with better performance of HE4 in our selected group of patients and combined serum protein levels of HE-4 with CA-125 improve the sensitivity obtained with only one tumor marker and their level was related to clinical staging. But, due to, "abnormally high concentrations of CA-125 found in many conditions and little is known about HE-4 diagnostic specificity till now in other benign and malignant conditions", both markers can be used for diagnosis and follow-up of patients taking in consideration their diagnostic specificity.

Keywords: Carbohydrate antigen 125 (CA-125), Human epididymis 4 (HE-4), Ovarian cancer, WAP Four-Disulfide Core Domain gene 2 (WFDC-2).

Abbreviation: OC: Ovarian Cancer; EOC: Epithelial Ovarian Cancer; FIGO: International Federation of Obstetrics and Gynecology; NEOCs: Non-Epithelial Ovarian Cancers. 


\section{Introduction}

Ovarian cancer is one of the most common, gynecologic cancers all over the world and the fourth most frequent cause of lethal malignancy in women [1]; it is incidence is variable with highest rates reported in North America and Europe [2]. Ovarian cancer can be curable in early diagnosed cases where the disease is limited to the ovaries; however, most cases are diagnosed in advanced stages III-IV, according to International Federation of Obstetrics and Gynecology (FIGO) classification; mortality is strongly related to disease stage: the 5 -year survival is $70 \%$ in stages I or II but decreases to $0 \%$ to $20 \%$ in stages III or IV, seeking for markers for diagnosis and improving the survival rate of patients is crucial [3-5]. Human Epididymis 4 (HE-4) protein, is the one of the gene product of WAP Four-Disulfide Core Domain gene (WFDC-2), a new candidate for ovarian cancer diagnosis [6, 7], the exact function of these proteins is poorly understood, but their status as likely extracellular protease inhibitors suggests that they may be involved in the regulation of extracellular matrix, cell migration and cell invasion [8], HE-4 functions is essential for sperm maturation. It is normally secreted only in very low concentrations by healthy ovaries [9]. The WFDC-2 gene is located on chromosome 20q12-13.1 www.genecard. org [10-13]; it is one of 14 homologous genes on this chromosome that encode proteins with WAP-type fourdisulphide core domains. It was initially identified in epithelial cells of human epididymis so it is also named Epididymis-Specific $[14,15]$. WFDC-2 gene expression has been found in healthy epithelial tissues such as the respiratory tract and female reproductive organs including ovaries and uterus. Hellstrom et, al. the first report mentioning HE-4 protein as a serum biomarker for ovarian cancer was published in 2003 [12]. HE-4 serum protein levels are less affected by menstruation, ovulation and other benign ovarian conditions (e.g. endometriosis) compared with the most evaluated marker for ovarian cancer diagnosis CA125. Moore et al., 2008 and several other publications [16-18] used a combination of HE-4, CA-125 serum protein levels for OC diagnosis and distinguish malignant from benign conditions. Although HE-4 has shown promise as a complement to CA-125 as reported by many studies with other contradicting result [19, 20], still further assessment is needed. In this study, we aimed to assess combined HE 4 and CA- 125 serum protein levels diagnostic value in selected patients for the study group with ovarian malignancy.

\section{Subjects and Methods}

\section{Subjects}

A clinical case control study, the selected patients for our study groups includes; forty nine subjects; 33 patients with ovarian cancer, 16 non cancer control group. The patients: women presenting and diagnosed with a pelvic mass from March 2015 to March 2016 at National Cancer Institute, Cairo University. According to the postoperative pathology results, the patients were classified as; ovarian cancer patients and patients with benign ovarian diseases. All patients had no other conditions and received no preoperative chemotherapy and other treatments. The malignant ovarian tumors, 33 cases include; 20 cases of papillary serous adenocarcinoma, 8 cases of mucinous adenocarcinoma, and 5 other ovarian cancer types (2 cases granulosa cell tumor, 1 case neuroendocrine tumor, 1 case endometroid and I case yolk sac tumor). There are 8 cases of well differentiated, 13 cases of moderately differentiated, 6 cases of poorly differentiated and 6 unclassified tumor. According to the staging method of the International Federation of Gynecology and Obstetrics (FIGO), clinical staging was classified 11 cases of stage I, 19 cases of stage III and 3 cases of stage IV. Baseline characteristics of ovarian cancer patients are demonstrated in Table 1. Non cancer control group include (10 cases) of benign ovarian diseases; 4 cases benign ovarian cysts, 3 cases thecoma, 2 cases mucinous cystadenoma, case serous cystadenoma and 6 healthy female volunteer.

The OC patients were aged 38 to 74 , with an average age of ( $52 \pm 8.3$ ) years old. Non cancer free group were aged, 20 70 with an average age of ( $48 \pm 15.6)$ years. All subjects of our study were with no breast/thyroid disease, and a history of other cancers.

Table 1. Patients characteristics and histo-pathological characteristics of ovarian tumor

\begin{tabular}{|l|l|}
\hline Criteria & Frequency\% \\
\hline Age & \\
\hline$<55$ & $19(57.58)$ \\
\hline$>55$ & $14(42.42)$ \\
\hline Number of Children & \\
\hline Null parity & $3(9)$ \\
\hline Multiparty & $30(91)$ \\
\hline Family history & \\
\hline Irrelevant (Negative) & $31(94.00)$ \\
\hline Positive family history of breast cancer & $1(3.00)$ \\
\hline Positive family history of ovarian cancer & $1(3.00)$ \\
\hline Histologic type & \\
\hline Serous adenocarcinoma & $20(60.60)$ \\
\hline Mucinous adenocarcinoma & $8(24.20)$ \\
\hline Others & $5(15.20)$ \\
\hline Tumor Grade & \\
\hline Well differentiated & $8(24.20)$ \\
\hline Moderately differentiated (grade II) & $13(39.40)$ \\
\hline Poorly differentiated (grade III) & $6(18.20)$ \\
\hline Unclassified & $6(18.20)$ \\
\hline FIGO Staging & \\
\hline IA & $7(21.20)$ \\
\hline IB & $3(9.10)$ \\
\hline IC & $1(3.00)$ \\
\hline IIIB & $14(42.40)$ \\
\hline IIIC & $5(15.20)$ \\
\hline IV & $3(9.10)$ \\
\hline & \\
\hline
\end{tabular}

\section{Methods}

Peripheral blood samples were obtained from patients, collection time before patient receive treatment, five-milliliter venous blood was collected, sample were retained 1 hour at room temperature, then the blood was centrifuged at $4000 \mathrm{rpm}$ for 10 minutes and serum was drawn and stored at -20 and $-80^{\circ} \mathrm{C}$ until use. Routine laboratory investigations include; complete blood count, liver biochemical profile, kidney function. Specific laboratory investigations include; serum concentration of $\mathrm{HE}-4$ was determined by Solid Phase Enzyme Immunoassay from XEMA Co, Itd, Mosco, Russia with cutoff value of $70 \mathrm{pMol} / \mathrm{L}$ (as suggested by Moore et al., 2008 [16] and Nolen et al 2010 [21] or 150 pMol/L (as 
suggested in the product insert), serum concentration of CA-125 was determined by ARCHITECT ${ }^{\circledR}$ chemiluminescent enzyme immunoassay (USA) according to the manufacturer's instructions with normal reference range of $<35 \mathrm{U} / \mathrm{ml}$ for CA-125. All procedure was conducted according to the manufacturer's instructions. Radiological investigations include abdominal ultrasonography, triphasic CT abdomen and/or dynamic MRI abdomen with MRI diffusion.

\section{Statistical Analysis}

All data were analyzed by SPSS software (version 21.0.0; IPM SPSS, Chicago, IL, USA). Descriptive summary statistics are presents for all demographic and baseline characteristics and measurement. Quantitative data were represented as mean, standard deviation (SD) and median (range). Categorical data were represented as number and percent. The distribution of quantitative variables was tested for normality using Kolmogorov-Smirnov test, Shapiro-wilk test. For statistical analysis, the independent samples student ( $t$ ) test was used comparing mean between two groups for parametric data, Mann Whitney tests for two group comparative analysis for non-parametric data. For categorical data chi-square test and fisher exact for small value were used. Receiver operating characteristic curve (ROC) analysis was used to calculate ideal cutoff value that provide the best and highest accuracy (minimal false-negative and false-positive results) and calculate sensitivity and specificity in our own study; we also determined sensitivity and specificity according to reference value. All statistical analysis was two sided with an alpha value (p) of less than 0.05 was considered statistically significant.

\section{Results}

\section{Serum HE-4 and CA-125 Protein Concentration Levels}

The serum protein level of HE-4 increased in patients with malignant ovarian cancer than that of non-cancer control group with statistically significantly difference mean (SD)/median (range) 329.61 $\pm 336.55 / 199(28.72-1064), 64.80 \pm 38.51 / 54.53(21-$ $160)(p<0.05)$ and the serum protein levels of CA-125 in patients with malignant ovarian cancer was statistically significantly higher than that of non-cancer control group 521.36 $\pm 572.60 / 287$ (10.50-2377), $28.35 \pm 10.80 / 28(10-50)(p<0.05)$ for all comparison Table 2.

Table 2. Serum HE-4, CA-125 protein levels in ovarian cancer and non-cancer group

\begin{tabular}{|l|l|l|l|l|l|l|l|l|}
\hline & \multicolumn{3}{|l|}{ HE-4 (pMol/L) } & \multicolumn{3}{l|}{ CA-125(U/ml) } \\
\hline & & Mean \pm SD & Median(R) & $\mathbf{p}$ & & Mean \pm SD & Median(R) \\
\hline Groups & & & & & & & & \\
\hline OC group & 33 & $329.61 \pm 336.55$ & $199(28.72-1064)$ & 0.001 & 33 & $521.36 \pm 572.60$ & $287(10.50-2377)$ \\
\hline Non cancer group & 16 & $64.80 \pm 38.51$ & $54.53(21-160)$ & & 10 & $28.35 \pm 10.80$ & $28(10-50)$ \\
\hline & & Mann-Whitney & & & & & \\
\hline
\end{tabular}

${ }^{*} \mathrm{P}<0.05-\mathrm{HE}-4$, human epididymis protein 4; CA-125, carbohydrate antigen 125; OC, ovarian cancer

\section{Serum HE-4 and CA-125 Protein Concentration Levels According to Demographic and Clinico-Pathological Data}

In malignant ovarian cancer group, the serum protein level of HE-4 and CA-125 were increased in women $>55$ women than women $<55$ with statistically significant difference was observed with CA-125 only $(p=0.04)$ Table 3.

The serum protein level of HE-4 and CA-125 were increased in serous than mucinous malignancies with statistically significant difference comparing the most frequent types in our study serous from mucinous types. Increased concentrations of both tumor markers with higher concentrations in combined grade II\&III than grade I and in advanced stage combined stage III\&IV than in early stage, stage I was with statistically significant difference Table 3.

Table 3. The serum protein levels of HE-4 and CA-125 according to demographic and clinico-pathological data in ovarian cancer patients

\begin{tabular}{|l|l|l|l|l|l|l|l|}
\hline & \multicolumn{3}{|c|}{ HE-4 (pMol/L) } & Median(R) & & Mean \pm SD & Median(R) \\
\hline & N & Mean \pm SD & & & & \\
\hline Age & & & & & & \\
\hline$<55$ & 19 & $293.77 \pm 325.12$ & $155.57(28.27-1064)$ & 0.48 & $460.36 \pm 572.46$ & $280(10.52-2377)$ \\
\hline$>55$ & 14 & $378.25 \pm 357.81$ & $243.26(52.65-1053)$ & & $604.13 \pm 583.53$ & $533(103-2259)$ \\
\hline Types & & & & & & & \\
\hline Serous & 20 & $433.55 \pm 388.07$ & $226.45(44.86-1064)$ & 0.02 & $733.19 \pm 603.79$ & $682(103-2377)$ \\
\hline Mucinous & 8 & $146.07 \pm 156.85$ & $74.31(28.72-451.36)$ & & $83.10 \pm 73.04$ & $79.65(10.5-195)$ \\
\hline Grades & & & & & & & \\
\hline Gradel & 8 & $146.26 \pm 142.67$ & $90.14(28.72-460.14)$ & 0.05 & $307.63 \pm 310.29$ & $133.50(13.70-730)$ \\
\hline Grade II III & 19 & $442.41 \pm 396.71$ & $208.26(44.86-1064)$ & & $718.00 \pm 656.00$ & $642(10.5-2377)$ \\
\hline Stage & & & & & & & 0.004 \\
\hline Stage I & 11 & $101.80 \pm 65.21$ & $89.95(28.72-245)$ & 0.001 & $196.11 \pm 328.19$ & $35.50(10.50-960)$ \\
\hline Stage III IV & 22 & $443.51 \pm 360.27$ & $330.29(44.86-1064)$ & & $683.98 \pm 604.32$ & $626.50(123.80-2377)$ \\
\hline
\end{tabular}

${ }^{*} \mathrm{P}<0.05-\mathrm{HE}-4$, human epididymis protein 4; CA-125, carbohydrate antigen 125

\section{Positive Frequency Rate of, HE-4 and CA-125 in Each Group}

As shown in Table 4, Abnormal serum HE-4 and CA-125 were found in 16 of $20(80 \%)$ and 20 of $20(100) \%$ of serous malignancies, 4 of $8(50 \%)$ and 5 of $8(62.5) \%$ of mucinous malignancies, abnormal serum HE-4 and CA-125 were found in
19 of $22(86.36 \%)$, and all cases (100\%) in advanced combined stage III\&IV, and 7 of $11(63.63 \%)$ and 6 of 11 (54.54\%) cases in stage $I$. The difference in proportion and statistical significance are shown Table 4. 
Table 4. The frequency distribution of HE-4 and CA-125 cases according to demographic and clinico-pathological datain ovarian cancer patients

\begin{tabular}{|c|c|c|c|c|c|}
\hline & & \multicolumn{2}{|l|}{ HE-4 (pMol/L) } & \multicolumn{2}{|l|}{ CA-125(U/ml) } \\
\hline & $\mathrm{N}$ & Number of positive cases & & Number of positive cases & p \\
\hline \multicolumn{6}{|c|}{ 帮 } \\
\hline$<55$ & 19 & $16(84.21)$ & 0.90 & $14(73.68)$ & 0.04 \\
\hline$>55$ & 14 & $12(85.71)$ & & $14(100)$ & \\
\hline \multicolumn{6}{|l|}{ Types } \\
\hline Serous & 20 & $16(80.00)$ & 0.001 & $20(100)$ & 0.004 \\
\hline Mucinous & 8 & $4(50.00)$ & & $5(62.50)$ & \\
\hline \multicolumn{6}{|l|}{ Grades } \\
\hline Grade I & 8 & $5(62.50)$ & 0.55 & $7(87.50)$ & 0.51 \\
\hline Grade II III & 19 & $15(78.90)$ & & $18(94.70)$ & \\
\hline \multicolumn{6}{|l|}{ Stage } \\
\hline Stage I & 11 & $7(63.63)$ & 0.03 & $6(54.54)$ & 0.002 \\
\hline \multirow[t]{2}{*}{ Stage III IV } & 22 & $19(86.36)$ & & $22(100)$ & \\
\hline & \multicolumn{5}{|c|}{ Chi-square or Fisher Exact for small value $<5$} \\
\hline
\end{tabular}

$* \mathrm{P}<0.05-\mathrm{CA}-125$, carbohydrate antigen 125; HE-4, human epididymis protein 4.

\section{Diagnostic Value of Separate and Combined Detection of HE-4, and CA-125 in Ovarian Cancer}

Receiver operator characteristic (ROC) curves were constructed, and the area under the curve (ROC-AUC) with a 95\% confidence interval was calculated. Based on the ROC curve, HE-4 values for the diagnosis of malignant ovarian tumors were observed that they have high diagnostic value in ovarian cancer. The Area under the curve (ROC-AUC) $(95 \% \mathrm{Cl})$ of HE-4 was calculated $0.85(0.74-0.95)$. The area under the ROC curve of serum markers HE-4 and CA-125 and their ideal cutoff value, sensitivity and specificity were show Table 5 \& Figure 1.

Table 5. Diagnostic value of separate and combined detection of HE-4, and CA-125 in ovarian cancer patients

\begin{tabular}{|c|c|c|c|c|c|c|c|c|}
\hline & \multirow[b]{2}{*}{ AUC $(95 \% \mathrm{Cl})$} & \multirow[b]{2}{*}{ Cutoff } & \multirow[b]{2}{*}{ Sig. } & \multicolumn{5}{|c|}{ Diagnostic Value } \\
\hline & & & & Sensitivity & Specificity & PPV & NPP & Accuracy \\
\hline \multicolumn{9}{|l|}{$\mathrm{HE}-4$} \\
\hline \multirow[t]{3}{*}{ All Cases vsControl } & 0.85 (0.74-0.95). & 67.50 & 0.00 & 84.84 & 75.00 & 87.50 & 70.50 & 81.60 \\
\hline & & 70.00 & & 81.81 & 75.00 & 87.00 & 66.66 & 79.59 \\
\hline & & 150.00 & & 57.57 & 93.75 & 95.00 & 51.72 & 69.38 \\
\hline $\begin{array}{l}\text { Stage I vs Control } \\
\text { CA-125 } \\
\text { Combined HE-4 CA-125 }\end{array}$ & $\begin{array}{l}0.70(0.50-0.90) \\
0.86(0.75-0.97)\end{array}$ & $\begin{array}{l}58.17 \\
34.00\end{array}$ & $\begin{array}{l}0.07 \\
0.001\end{array}$ & $\begin{array}{l}63.63 \\
84.84 \\
90.90\end{array}$ & $\begin{array}{l}62.50 \\
60.00 \\
50.00\end{array}$ & $\begin{array}{l}53.84 \\
87.50 \\
85.70\end{array}$ & $\begin{array}{l}71.42 \\
54.54 \\
62.50\end{array}$ & $\begin{array}{l}62.96 \\
79.06 \\
81.39\end{array}$ \\
\hline
\end{tabular}

${ }^{*} \mathrm{P}<0.05 /$ PPV: Positive predictive value; NPP: Negative predictive value

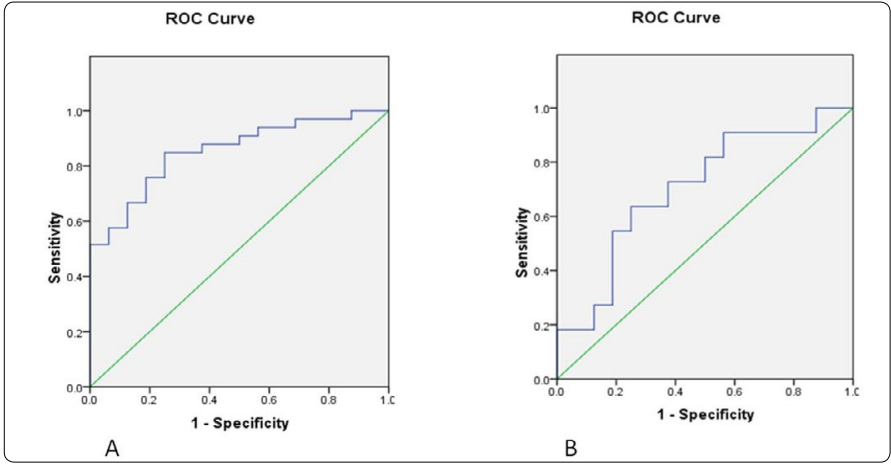

Figure 1. The receiver operating characteristic curve, the area under the curve $(95 \% \mathrm{Cl})$ for $\mathrm{HE}-4$

A) ovarian cancer vs non-cancer group 0.85 (0.74-0.95). / B) ovarian cancer (stage I) vs non-cancer group 0.70 (0.50-0.90).

\section{Discussion}

Ovarian malignancy is a heterogeneous group of diseases comprised of invasive epithelial cancers, borderline epithelial tumors with low malignant potentials and non-epithelial cancers. Epithelial ovarian cancer is the highest mortality cancer in obstetrics and gynecology. It is also the fifth leading cause of female deaths [22]. Siegel et al in 2016; reported that; there were 22,280 new cases worldwide with 14,240 deaths [23]. The targets for ovarian cancer screening are the invasive epithelial cancers as they are responsible for the vast majority of the deaths. Five major subtypes among epithelial tumors, papillary serous, endometroid, mucinous, clear cell, and transitional, more than half of all primary ovarian cancers will be serous epithelial carcinomas [16].

In this study, the majority of the malignant tumors were epithelial ovarian cancer (EOC), other primary non epithelial ovarian tumors (NEOCs) include two granulosa cell tumor and I yolk sac tumor.

CA-125 is the most evaluated marker for ovarian cancer detection and monitoring. Its level is raised in approximately $50 \%$ of stage I and approximately $90 \%$ of the stage II epithelial cancers $[2,14]$, although it is widely used, its low specificity with abnormally high concentrations found in many malignancies of different origin, "including other gynecologic cancers (endometrium, endocervix), non-gynecologic conditions and in premenopausal women limit its diagnostic value especially as a marker for early diagnosis [24-25].

$\mathrm{HE}-4$ is a new candidate for ovarian cancer diagnosis, previous result on gene expression stated overexpression in ovarian cancer types [11, 13], WFDC-2 gene, it's among the most frequently upregulated genes in epithelial ovarian cancer based on gene expression profiles [25-30], some expression has also been found in pulmonary, endometrial, and breast adenocarcinomas, mesotheliomas, and less often, gastrointestinal, renal, and transitional cell carcinomas [31, 32]. 
Human epididymis protein 4 (HE-4) is recently identified serum tumor marker, specifically secreted in ovarian cancer [33], endometrial cancer [34, 35] and gastric cancer [36]. Several studies suggested $\mathrm{HE}-4$ gene product has similar diagnostic sensitivity to that of CA-125, with an increased diagnostic specificity in patients with gynecologic malignancies compared with those with a benign gynecologic disease $[9,13,28]$. In contrast, many studies [19,20,37], stated that, $\mathrm{HE}-4$ alone or in combination with CA-125 do not achieve better diagnostic performance than CA-125 alone. Many studies stated; combined $\mathrm{HE}-4$ and $\mathrm{CA}-125$ improve the diagnostic value than each of them alone $[3,7,9,17,22]$.

Our results showed increased serum protein concentration levels of HE-4 and CA-125 in the sera of the ovarian cancer group than that of the benign group with statistically significant difference $(p<0.05)$. Both tumor markers show increased serum concentrations of HE- 4 and CA- 125 in sera of the women $>55$ than that of $<55$ in $O C$ group with statistically significant difference was observed with CA-125 only $(p<0.05)$.

The levels of HE-4 were related to histologic types, tumor grade differentiation and clinical staging. The serous ovarian cancer was the most frequent histologic type in our study (60.60\%), an increased serum concentration of HE-4 was observed in serous ovarian cancer compared to mucinous type with significant difference was observed. Our finding agrees with result stated by Moore et al., 2008, Escudero et al., 2011 [13, 16], $\mathrm{HE}-4$ is secreted at high concentration in serous OC and low levels in mucinous type. The serum concentration levels and the positive frequency rate of $\mathrm{HE}-4$ were increased with progression of disease with higher concentration in combined grade II\&III (moderate and poor differentiated) and combined stage III\&IV (advanced stage) OC than grade I (well differentiated) and stages I (early stage) OC with statistically significant difference $(p<0.05)$, the levels of CA-125 was related, histologic type, tumor grade differentiation and clinical staging.

In selected patients for the study group with ovarian malignancy, the optimum sensitivity and specificity for HE-4 was obtained at ROC-AUC a cutoff level of 67.50 (Cancer vs. non cancer group), the ROC-AUC was 0.85 with sensitivity and specificity of (84.84\% \& $75.00 \%)$. In addition, we compared the most common cut-off for $\mathrm{HE}-4$ used in previous investigations at $70 \mathrm{pMol} / \mathrm{L}$ and $150 \mathrm{pMol} / \mathrm{L}$, at this cut-off the sensitivity and specificity were (81.81\% \& $75.00 \%)$ (57.57\% \&93.75\%) respectively. For stage I, HE-4 is a promising biomarker for early diagnosis ROC-AUC was 0.70 (Ovarian cancer vs. non cancer group) with sensitivity and specificity of $(63.63 \& 62.50)(p=0.07)$, The ROCAUC for CA-125 in our study (all cases or stage I) were obtained at a cutoff level of 34.0 (Cancer vs. non cancer group) the same with all established recommendation for cutoff value of CA-125 with sensitivity and specificity (84.84\&60.00) (54.54\&60.00).

Due to small sample size, stage I EOC was not divided into a pre- and postmenopausal group in the analysis, which could have affected the individual biomarkers performance.

Several studies for serum levels of $\mathrm{HE}-4$ has been already published that it has sensitivity and specificity were better than CA-125 with other contradicting finding. Our results shows comparable diagnostic value was achieved for $\mathrm{HE}-4$ with $\mathrm{CA}-125$ with better performance of HE4 in our selected group of patients with an increased diagnostic specificity. Our finding shows combined HE-4 and CA-125 improve the sensitivity obtained with only one tumor marker to $90.90 \%$ all cases, promising performance in stage $163.63 \%(p=0.07)$ indicating the use of HE-4 together with CA-125 may improve the detection of ovarian cancer. Because the number of serum samples we tested was small, our result was just preliminary and might have some limits. A larger number of $O C$ samples need to be detected to substantiate our results and its possibility for use in clinic in the future.

Our results are in agreement with recent studies conducted on ovarian cancer stated $\mathrm{HE}-4$ a new marker with promising result; HE-4 combined with CA-125 is helpful in diagnosis of epithelial ovarian cancer [22].

\section{Conclusion}

Our result shows combined HE-4 with CA-125 serum protein levels can improve the ovarian cancer diagnosis compared with use of either marker alone and their level was related to clinical staging and discriminating malignant from benign conditions with promising results for $\mathrm{HE}-4$ measurement during early stage but due to, "abnormally high concentrations of CA- 125 found in many conditions and little is known about HE-4 diagnostic specificity till now in other benign and malignant conditions", both markers can be used for diagnosis and follow-up of patients taking in consideration their diagnostic specificity.Therefore, HE-4 or CA125 is rarely used as a unique parameter in the prediction of malignancy. Usually, a combination of a patient's medical history, clinical examination results, imaging data and tumor marker profile with other laboratory data is used. Further assessment still needed.

\section{Ethical Approval}

The study protocol was reviewed and approved by the Ethics Committee of the National Cancer Institute.

\section{Informed Consent}

Informed consent has been obtained from all participants according to human ethics committee approval.

\section{Conflict of Interest}

Authors state no conflict of interest

\section{Author Contributions}

All authors confirmed they have contributed to the intellectual content of this paper.

Idea: Reham El Shimy

Conception and design: SalwaTeama, Reham El Shimy, Hebatallah Gamal

Provision of study material or patients: Reham El Shimy, Hebatallah Gamal

Collection and assembly of data: Reham El Shimy

Data analysis and interpretation: SalwaTeama

Manuscript writing: SalwaTeama

Final approval of Manuscript: SalwaTeama, Reham El Shimy, Hebatallah Gamal 


\section{References}

1. Wei S, Li H, Zhang B. The diagnostic value of serum HE4 and CA125 and ROMA index in ovarian Cancer. Biomed Rep. 2016; 5(1):41-44. doi: 10.3892/br.2016.682

2. Basu P, Vale D. Screening for epithelial ovarian cancer: an updated review. Indian J Gynecol Oncolog. 2017; 15(1): 1-8. doi: 10.1007/S40944-017-0100-X

3. Yancik R. Ovarian cancer. Age contrasts in incidence, histology, disease stage at diagnosis, and mortality. Cancer. 1993; 71(2): 517-523.

4. Thigpen T, Vance RB, McGuire WP, Hoskins WJ, Brady M. The Role of paclitaxel in the management of coelomic epithelial carcinoma of the Ovary: A review with emphasis on the gynecologic oncology group experience. Semin Oncol 1995; 22(6):23-31.

5. Narakorn C, Eds. Srisomboon J, Wilailak S. Epithelial ovarian cancer. In: Gynecologic Oncology Pimdee. 2011; 199-243.

6. Kirchhoff $C$, Habben I, Ivell R, Krull N. A major human epididymis-specific cDNA encodes a protein with sequence homology to extracellular proteinase inhibitors.BiolofReprod. 1991;45(2):350-357.doi:10.1095/biolreprod45.2.350

7. Schummer M, Ng WV, Bumgarner RE, Nelson PS, Schummer B, Bednarski DW, et al. Comparative hybridization of an array of 21,500 ovarian cDNAs for the discovery of genes overexpressed in ovarian carcinomas. Gene. 1999; 238(2): 375-385.

8. Zhuang H, Tan M, Liu J, Hu Z, Liu D, Gao G, et al. Human Epididymis Protein 4 in association with annexin II promotes invasion and metastasis of ovarian cancer cells. Mol Cancer. 2014; 13: 243. doi: 10.1186/1476-4598-13-243

9. Moore RG, Brown AK, Miller MC, Skates S, Allard WJ, Verch T, et al. The use of multiple novel tumor biomarkers for the detection of ovarian carcinoma in patients with a pelvic mass. Gynecol Oncol. 2008; 108(2): 402-408. doi: 10.1016/j.ygyno.2007.10.017

10. www.genecard.org. Available at: https://www.genecards.org/cgi-bin/ carddisp.pl?gene=WFDC2

11. Bingle $L$, Singleton $V$, Bingle $C D$. The putative ovarian tumor marker gene HE4 (WFDC2) is expressed in normal tissues and undergoes complex alternative splicing to yield multiple protein isoforms. Oncogene. 2002; 21(17): 2768-2773. doi: 10.1038/sj.onc.1205363

12. Hellstrom I, Raycraft J, Hayden-Ledbetter M, Ledbetter JA, Schummer M, McIntosh M, et al. The HE4 (WFDC2) Protein is a biomarker for ovarian carcinoma. Cancer Res. 2003; 63(13): 3695-3700.

13. Escudero JM, Jose M, Auge, Filella X, Torne A, Pahisa J, et al. Comparison of serum Human Epididymis Protein 4 with Cancer Antigen 125 as a tumor marker in patients with malignant and nonmalignant diseases. Clin Chem. 2011; 57(11): 1534-1544. doi: 10.1373/clinchem.2010.157073

14. Bast RC Jr, Badgwell D, Lu Z, Marquez R, Rosen D, Liu J, et al. New tumor markers: CA125 and beyond. Int J Gynecol Cancer. 2005; 15(3): 274-281. doi: 10.1111/j.1525-1438.2005.00441.x

15. Celik B, Bulut T. Human Epididymis Protein 4 may not be a reliable screening biomarker for detecting lung carcinoma patients. Biomed Rep. 2017; 7(4): 297-300. doi: 10.3892/br.2017.971

16. Moore RG, McMeekin DS, Brown AK, DiSilvestro P, Miller MC, Allard WJ, et al. A Novel multiple marker bioassay utilizing HE4 and CA125 for the prediction of ovarian cancer in patients with a pelvic mass. Gynecol Oncol. 2009; 112(1): 40-46. doi: 10.1016/j.ygyno.2008.08.031

17. Woolas RP, Xu FJ, Jacobs IJ, Yu YH, Daly L, Berchuck A, et al. Elevation of multiple serum markers in patients with stage I ovarian cancer. J Natl Cancer Inst. 1993; 85(21): 1748-1751.

18. Van Gorp T, Cadron I, Despierre E, Daemen A, Leunen K, Amant F, et al. HE4 and CA125 as a diagnostic test in ovarian cancer: Prospective validation of the risk of ovarian malignancy algorithm. Br J Cancer. 2011; 1; 104(5): 863-870. doi: 10.1038/sj.bjc.6606092

19. Ferraro S, Braga F, Lanzoni M, Boracchi P, Biganzoli EM, Panteghini M. Serum Human Epididymis Protein 4 vs Carbohydrate Antigen 125 for ovarian cancer diagnosis: a systematic review. J Clin Pathol. 2013; 66(4): 273-281. doi: 10.1136/jclinpath-2012-201031
20. Zhen S, Bian LH, Chang LL, Gao X. Comparison of Serum Human Epididymis Protein 4 and Carbohydrate Antigen 125 as markers in ovarian cancer: A Meta-analysis. Mol Clin Oncol. 2014; 2(4): 559-566. doi: 10.3892/ mco.2014.279

21. Nolen B, Velikokhatnaya L, Marrangoni A, De Geest K, Lomakin A, Bast, et al. Serum biomarker panels for the discrimination of benign from malignant cases in patients with an adnexal mass. Gynecol Oncol. 2010; 117(3): 440-445. doi: 10.1016/j.ygyno.2010.02.005

22. Tuerxun $H$, Tuerxun $M$, Maimaitituersun $G$, Yilihamu $Y$, Maimaitiming $W$, Aierken $G$ et al. Significance of serum CA-125 combined with CEA and HE-4 in diagnosis of epithelial ovarian cancer. Int J Clin Exp Med. 2018; 11(4):4156-4161.

23. Siegel RL, Miller KD, Jemal A. Cancer statistics, 2016. CA Cancer J Clin. 2016; 66: 7-30.

24. Urban N, Mclntosh MW, Andersen M, Karlan. Ovarian cancer screening. Hematol Oncol Clin North Am. 2003; 17(4): 9891005. doi: 10.1016/S08898588(03)00063-7

25. Duffy MJ, Bonfrer JM, Kulpa J, Rustin GJ, Soletormos G, Torre GC, et al. CA125 in Ovarian Cancer: European group on tumor markers guidelines for clinical use. Int J Gynecol Cancer. 2005; 15(5): 679-691. doi: 10.1111/j.1525-1438.2005.00130.x

26. Ono K, Tanaka T, Tsunoda T, Kitahara O, Kihara C, Okamoto A, et al. Identification by cDNA microarray of genes involved in ovarian carcinogenesis. Cancer Res. 2000; 60(18): 5007-5011.

27. Shridhar V, Lee J, Pandita A, Iturria S, Avula R, Staub J, et al. Genetic analysis of early- versus late-stage ovarian tumors. Cancer Res. 2001; 61(15): 5895-5904.

28. Welsh JB, Zarrinkar PP, Sapinoso LM, Kern SG, Behling CA, et al. Analysis of gene expression profiles in normal and neoplastic ovarian tissue samples identifies candidate molecular markers of epithelial ovarian cancer. Proc Natl Acad Sci U S A. 2001; 98(3): 1176-1181. doi: 10.1073/pnas.98.3.1176

29. Drapkin $R$, von Horsten $H H$, Lin $Y$, Mok SC, Crum PC, Welch WR et al. Human Epididymis Protein 4 (HE4) is a secreted glycoprotein that is overexpressed by serous and endometrioid ovarian carcinomas. Cancer Res. 2005; 65(6): 2162-2169. doi: 10.1158/0008-5472.CAN-04-3924

30. Hough CD, Sherman-Baust CA, Pizer ES, Montz FJ, Im DD, et al. Largescale serial analysis of gene expression reveals genes differentially expressed in ovarian cancer. Cancer Res. 2000; 15; 60(22): 6281-6287.

31. Jacobs IJ, Menon U. Progress and challenges in screening for early detection of ovarian cancer. Mol Cell Proteomics. 2004; 3(4): 355-366. doi: 10.1074/mcp.R400006-MCP200

32. Galgano MT, Hampton GM, Frierson HF. Comprehensive analysis of HE4 expression in normal and malignant human tissues. Mol Pathol. 2006; 19(6): 847-853. doi: 10.1016/j.ygyno.2017.08.020

33. Simmons AR, Baggerly K, Bast RC. The Emerging role Of HE4 in the evaluation of epithelial ovarian and endometrial carcinomas. Oncology (Williston Park). 2013; 27(6): 548-556.

34. McKinnon B, Mueller MD, Nirgianakis K, Bersinger NA. Comparison of ovarian cancer markers in endometriosis favors HE4 over CA125. Mol Med Rep. 2015; 12(4): 5179-5184. doi: 10.3892/mmr.2015.4062

35. Tang QF, Zhou ZW, Ji HB, Pan WH, Sun MZ. Value of serum marker HE4 in pulmonary carcinoma diagnosis. Int J ClinExp Med. 2015; 8(10): 1901419021.

36. Guo YD, Wang JH, Lu H, Li XN, Song WW, Zhang XD, et al. The Human Epididymis Protein 4 acts as a prognostic factor and promotes progression of gastric cancer. Tumor Biol. 2015; 36(4): 2457-2464. doi: 10.1007/s13277-014-2858-0

37. Shobeiri MJ, Parizad M, Nazari F, Ouladsahebmadarek E, Sayyah-Melli M, ParvinMostafa-Gharabaghi PM, et al. Diagnostic value of HE4, CA125 and risk of ovarian malignancy algorithm in detecting ovarian cancer. International Journal of Women's Health and Reproduction Sciences. 2015; 3(4): 208-211. doi: 10.15296/ijWhr.2015.43 